\title{
Spectral Evaluation Studies on Titanium Dioxide Nano-Particles and Their Add-mixtures on Textile Fabrics
}

Saher F. Ibrahim*, Dalia. M. Essa and Eman M. Osman

National Institute for Standards, Tersa st. Elharam, Giza, Egypt.

\begin{abstract}
HIS article aims to study the effect of the treatment of different textile fabrics: wool, polyester, and blend wool/polyester with nano-titanium dioxide. Where, nano- $\mathrm{TIO}_{2}$ used in the valid and safe concentrations range in accordance with many environmental legislations, in water dispersions matrices containing poly ethylene glycol (PEG) as a wetting agent and hydroxyl ethyl cellulose (HEC) as a thickening agent. FTIR spectral analysis, the UV-blocking performance, anti-bacterial activity, conductance measurement, electron spin resonance and air permeability were the techniques for characterization. The results obtained showed excellent antiultraviolet performance and improved antibacterial activity. The results of electrical characteristics verified a reduction percentage in the ohmic resistance of the treated fabrics indicating fabrics with improved electrical character. Also, the ESR results confirmed more surface activation of the modified fabrics. These modified fabrics with improved UV protection properties, antibacterial activity and electrical characteristics may referred so as called cosmetic and smart textiles.
\end{abstract}

Keywords: Nano- $\mathrm{TiO}_{2}$, Fabrics, Treatment, Conductance measurement, UV, Blocking, FTIR, Electron spin resonance and Air permeability.

The usage of nanotechnology provides the ability to engineer the characteristics of materials. Recently, the research of functionalization of fabric by application of the nano-materials and application of nano-technology was published such as UV-protection, far-infrared healthy, antistatic and anti-bacteria ${ }^{(1)}$. Numerous methods can apply coating onto fabrics, including spraying, transfer printing, washing, rinsing and padding, of these methods, padding is the most commonly used $^{(2,3)}$.

Many researchers ${ }^{(4)}$ studied the UV-absorbing properties of different nanomaterials that could be used as UV-absorber, such as nano-titanium dioxide, nano-zinc oxide, nano-silicon dioxide, nano-aluminum dioxide and etc, among which nano-titanium dioxide (Titania, $\mathrm{TiO}_{2}$ ) has gained widespread attention over recent decades. This wide usage of nano- titanium dioxide is mainly due to

\footnotetext{
* Corresponding author: E-mail: drsaherfawzy09@hotmail.com
} 
its unique properties such being chemically inert, semiconducting material that also exhibits photocatalytic activity in the presence of light with an energy equal to or higher than its band-gap energy. These characteristics offer a wide range of applications. Also, titanium dioxide exhibits relatively low price of the raw materials and its processing.

The textile materials are well known to be a polymer based material of a very good electrical Insulation, where, the dominating covalent bonds within the molecular polymer structure are the main reason of this electrical characteristic providing an isolating character of these textile fabrics ${ }^{(5)}$. Although the isolating character of the textile fabrics is not disturbing the majority of the common applications of them, in some cases of technical applications it is desired to have an increased electrical conductivity of the textile materials. Generally, it is assumed that the electrical conductivity of textile fabrics should be higher for the higher degree of crystallinity and better alignment of the chain

${ }^{(6-8)}$. Thus, many technologies have been proposed for the increase of the conductivity of the textile fibres such as the functionalization of them via usage of nano- titanium dioxide finishing agents that could enhance the fabrics electrical characteristics ${ }^{(9,10)}$. Where, many applications of the electrically conductive fabrics may be used in the field of aerospace and polar or deep diving conditions ${ }^{(11)}$.

The objective of the present study was to characterize the treatment of different textile fabrics: wool, polyester, and blend wool/polyester with nanotitanium dioxide of concentrations varying by three different percentages $[0.5$, 1.5 , and 3.0$] \mathrm{mg} / \mathrm{ml}$ in water dispersions containing poly ethylene glycol (PEG) in the amount of $10 \%(\mathrm{wt} / \mathrm{wt})$ as a wetting agent and hydroxyl ethyl cellulose (HEC) in the amount of $1 \%$ (wt/wt.) as a thickening agent.

\section{Fabrics}

\section{Experimental}

Pure wool fabrics $(100 \%)$, weight $(130) \mathrm{gm} / \mathrm{m}^{2}$, thickness is $(0.348) \mathrm{mm}$. Pure polyester fabrics $(100 \%)$, weight $(134) \mathrm{gm} / \mathrm{m}^{2}$, thickness is $(0.366) \mathrm{mm}$. Blend (wool / polyester 65/35\%) fabrics, weight $143.78 \mathrm{gm} / \mathrm{m}^{2}$, thickness is (0.3835) $\mathrm{mm}$. These fabrics were kindly supplied by Golden Tex Company, Egypt, and purified in a laboratory by scouring with a solution containing (2.0) $\mathrm{gm} / \mathrm{l}$ of non-ionic detergent using a liquor ratio (1:50) at temperature $60^{\circ} \mathrm{C}$ for (15) minutes and finally thoroughly washed with tap water and dried at ambient conditions.

\section{Chemicals}

a) Titanium dioxide of titanium (iv) oxide nano powder of $21 \mathrm{~nm}$ particle size $($ TEM) $99.9 \%$ trace metal basis , molecular weight $=79.87 \mathrm{~g}$, density $=4.26$ $\mathrm{g} / \mathrm{ml}$ at $25^{\circ} \mathrm{C}$, supplied by SIGMA, Aldrich . 
b) Poly (ethylene glycol) (PEG) $\mathrm{HOCH}_{2} \mathrm{CH}_{2} \mathrm{OH}$ of $400 \mathrm{~g} / \mathrm{mol}$ mean mass, and hydroxy ethyl cellulose of molecular formula: $\left[\mathrm{C}_{6} \mathrm{H}_{7} \mathrm{O}_{2}(\mathrm{OH})_{3^{-}}\right.$ $\left.\left[\left(\mathrm{OCH}(\mathrm{OH}) \mathrm{CH}_{3}\right)\right]_{3-\mathrm{x}}\right]_{n}(\mathrm{HEC})$ of low molar mass were used as chemical agents used for dip-coating:

\section{Dip coating method}

The incorporation of nano- $\mathrm{TIO}_{2}$ particles into the structure of each of the examined fabrics that are: wool, polyester and wool/polyester blend fabrics were realized by dip-coating of the fabric in the water dispersion of nano- $\mathrm{TIO}_{2}$ dioxide of concentrations varying by three different percentages $[0.5,1.5$, and $3.0] \mathrm{mg} / \mathrm{ml}$ in water dispersions containing poly ethylene glycol (PEG) in the amount of $10 \%$ (wt/wt) as a wetting agent and hydroxyl ethyl cellulose (HEC) in the amount of $1 \%(\mathrm{wt} / \mathrm{wt}$.) as a thickening agent, keeping the material to liquor ratio (1: 50). The usage of (PEG) and (HEC) was for improving the fixation of nano- $\mathrm{TIO}_{2}$ into the fabric surface for increasing the durability of modification even after cycles of washing ${ }^{(12)}$.

The used concentration range of nano- $\mathrm{TIO}_{2}(0.5-3.0 \mathrm{mg} / \mathrm{ml})$ was chosen to be in the valid and safe concentration range of the nano- $\mathrm{TIO}_{2}$ in accordance with much environmental legislation ${ }^{(13-17)}$.

Each of the prepared dispersion with the definite concentration for each percent was vigorously stirred by a homogenizer, working at a rate of (20000) r.p.m. for 60 seconds. Then each of tested samples was immersed in the nano$\mathrm{TIO}_{2}$ water dispersed forms for $30 \mathrm{~min}$. Then the treated fabrics were padded and squeezed followed by drying at $100^{\circ} \mathrm{C}$ in stationary drier for $1 \mathrm{~min}{ }^{(12)}$, then subjected to thermal fixation at $140^{\circ} \mathrm{C}$ for 6 min. Finally, the finished fabrics were washed with water and dried at ambient conditions.

\section{Characterization tools}

\section{Surface chemistry}

Fourier transform infrared spectroscopic analysis (FTIR)

The FTIR spectra absorbance frequencies for all the tested samples were recorded by means of Nicolet 380 Spectrometer in the wavelength range (400$4000) \mathrm{cm}^{-1}$ with an average of 128 scans using a resolution of (4.0) $\mathrm{cm}^{-1}$.

\section{Electron spin resonance (ESR)}

The ESR spectra of blank treated samples and those pre-treated with nano$\mathrm{TiO}_{2}$ under the effect of different nano- $\mathrm{TiO}_{2}$ concentrations were recorded using an X-band ESR spectrometer (Bruker, EMX) at room temperature with high sensitivity standard cylindrical cavity (ER 4119 HS) operating at (9.7) GHZ and having (100) $\mathrm{kHz}$ modulation frequency ${ }^{(18)}$.

\section{Ultraviolet protection factor (UPF)}

The UPF (ultraviolet protection factor) is a numerical rating given to clothing to indicate how effectively the fabric blocks ultraviolet (UV) radiation. 
The transmittance and UPF values of the examined fabric samples were measured using a Varian (UV-VIS-NIR) spectrophotometer according to the reported standard test method ${ }^{(19)}$. The UPF value of the fabric therefore is determined from the total spectral transmittance all over the range. Whereas, the UV-B Transmittance mean value percentage in the range (290-315) $\mathrm{nm}$ and the UV-A Transmittance mean value percentage in the range $(315-400) \mathrm{nm}$. The tested samples were classified according to their UPF values : <15 Poor, 15 to 24 Good, 25-39 Very Good, > 39 Excellent ${ }^{(20)}$.

\section{Antibacterial activity}

Antibacterial activity of the examined fabric samples was evaluated according to the reported standard method ${ }^{(21)}$. The incubation period of the tested microorganisms was 24 hours at $37{ }^{\circ} \mathrm{C}$. The tested microorganisms are Staphylococcus aureus (Gram-positive) and Escherichia coli (Gram-negative). The diameter of inhibition zone surrounding the sample was taken as a measure of the fabric activity against the particular test organism.An average value of three measurements was evaluated.

\section{Conductance measurements}

The conductance measurements for all the tested samples were recorded using E-4980 a Precision LCR-Meter $20-\mathrm{HZ}$ to $2.0 \mathrm{MHZ}^{(22)}$.

\section{Air permeability}

Measurement of air permeability of different fabric samples that are: wool, polyester and wool/polyester blends treated with different nano- $\mathrm{TiO}_{2}$ concentration and their blank fabrics were measured using SDL Air permeability tester-England, according to standard test method ${ }^{(23)}$.

\section{Results and Discussion}

\section{Surface chemistry (FTIR) results}

The FTIR spectral finger print (Fig. 1-3 a,b) of different fabric samples that are: polyester, wool, and wool/polyester blends modified with different nano- $\mathrm{TiO}_{2}$ concentration-figure 3-b for each fabric was selected as an example of the all obtained figures for modified samples of highest $\mathrm{TiO}_{2}$ concentration(percent $3=3 \mathrm{mg} / \mathrm{ml}$ )- and their blank fabrics assigned as figure (3-a) for each blank fabricfrom them the absorptions of characteristic functional groups of each fabric can be discussed as follows:

FTIR spectrum of $\mathrm{TiO}_{2}$ sample shows transmittance peaks in the range 500$1000 \mathrm{~cm}^{-1}$. This is assigned to the vibrations of $\mathrm{Ti}-\mathrm{O}$ and $\mathrm{Ti}-\mathrm{O}-\mathrm{Ti}$ framework bonds ${ }^{(24)}$. FTIR spectrum of polyester showed: $\mathrm{CH}_{2}$ antisymetric stretching $\left.2945 \mathrm{~cm}^{-1}\right), \mathrm{C}=\mathrm{O}$ anti-symmetric stretching $\left(1725 \mathrm{~cm}^{-1}\right)$, standard absorption-OH band $\left(1410 \mathrm{~cm}^{-1}\right), \mathrm{C}-\mathrm{H}$ stretching second overtone $\left(1143 \mathrm{~cm}^{-1}\right), \mathrm{O}-\mathrm{CH}_{2}$ stretching $\left(973 \mathrm{~cm}^{-1}\right)$, benzenoid group $\left(868 \mathrm{~cm}^{-1}\right)$. FTIR spectrum of wool showed $\mathrm{O}-\mathrm{H}$ (3370-3456 cm-1), $\mathrm{NH}^{3+}$ amino-side group (3100-2600) $\mathrm{cm}^{-1}, \mathrm{C}=\mathrm{O}\left(1700 \mathrm{~cm}^{-1}\right)$, 
NH-Amide I stretching (Imino) $1650 \mathrm{~cm}^{-1}$, COO- carboxy-late ion group (1600$\left.1590 \mathrm{~cm}^{-1}\right)$, cystine oxides $\left(1070-1200 \mathrm{~cm}^{-1}\right)$, tyrosine $\left(840-896 \mathrm{~cm}^{-1}\right)$, S-S disulphide signal (500-590) $\mathrm{cm}^{-1}$. FTIR spectrum of blend wool/polyester showed $\mathrm{O}-\mathrm{H}\left(3370-3456 \mathrm{~cm}^{-1}\right), \mathrm{NH}^{3+}$ amino-side group $(3100-2600) \mathrm{cm}^{-1}, \mathrm{C}=\mathrm{O}\left(1700 \mathrm{~cm}^{-1}\right)$, $\mathrm{NH}$-amide I stretching (Imino) $1650 \mathrm{~cm}^{-1}$, COO- carboxy-late ion group (1600-1590 $\mathrm{cm}^{-1}$ ), cystine oxides (1070-1200 $\mathrm{cm}^{-1}, \mathrm{CH}_{2}$ anti-symmetric stretching $\left.2945 \mathrm{~cm}^{-1}\right)$, $\mathrm{C}=\mathrm{O}$ anti-symmetric stretching $\left(1725 \mathrm{~cm}^{-1}\right)$, standard absorption-OH band $(1410$ $\left.\mathrm{cm}^{-1}\right)$, C-H stretching second overtone $\left(1143 \mathrm{~cm}^{-1}\right), \mathrm{O}_{-} \mathrm{CH}_{2}$ stretching $\left(973 \mathrm{~cm}^{-1}\right)$, benzenoid group $\left(868 \mathrm{~cm}^{-1}\right)^{(25)}$.
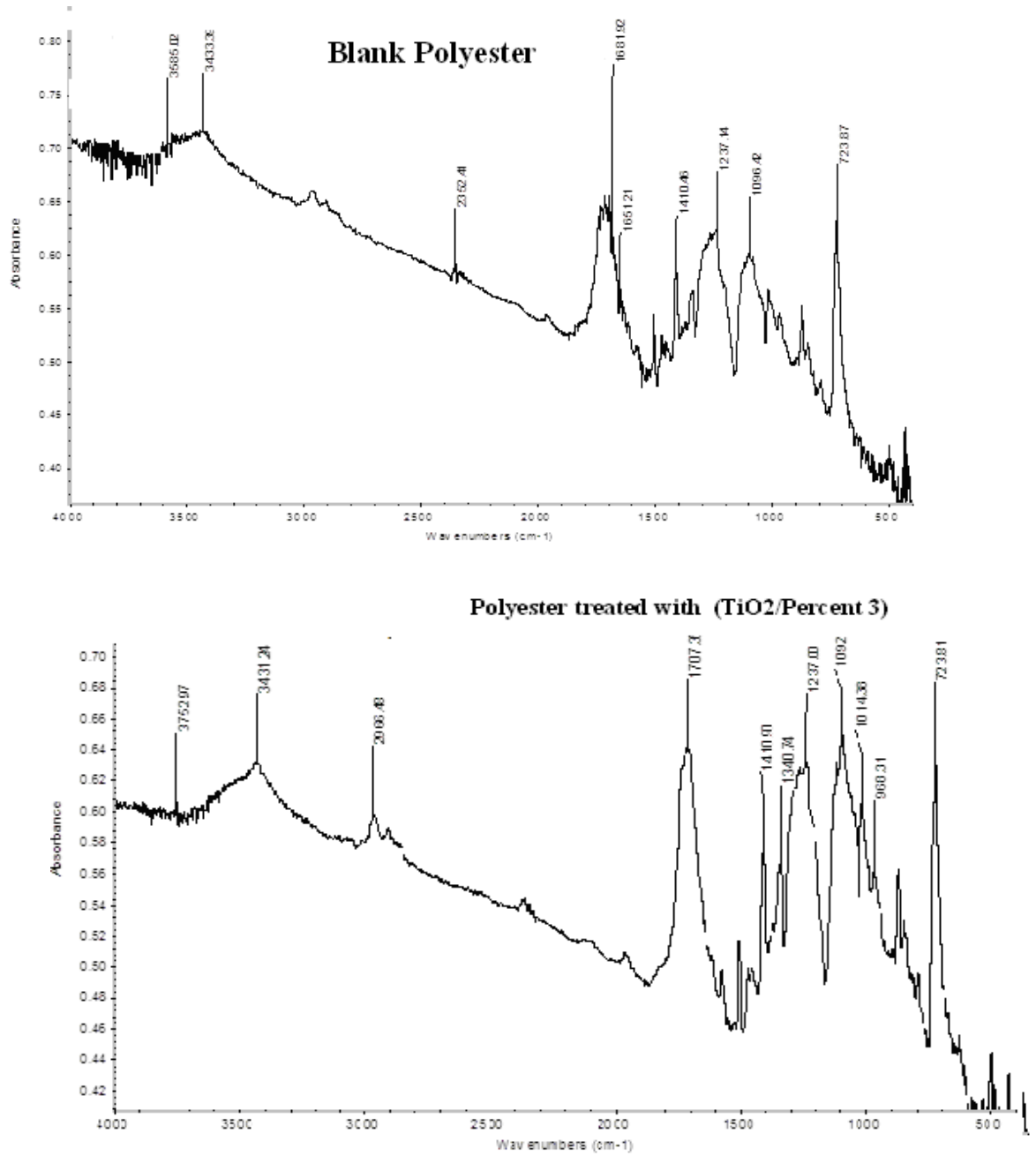

Fig.1.a-b. The IR finger print spectra of polyester fabrics.

Egypt. J. Chem. 59, No. 6 (2016) 

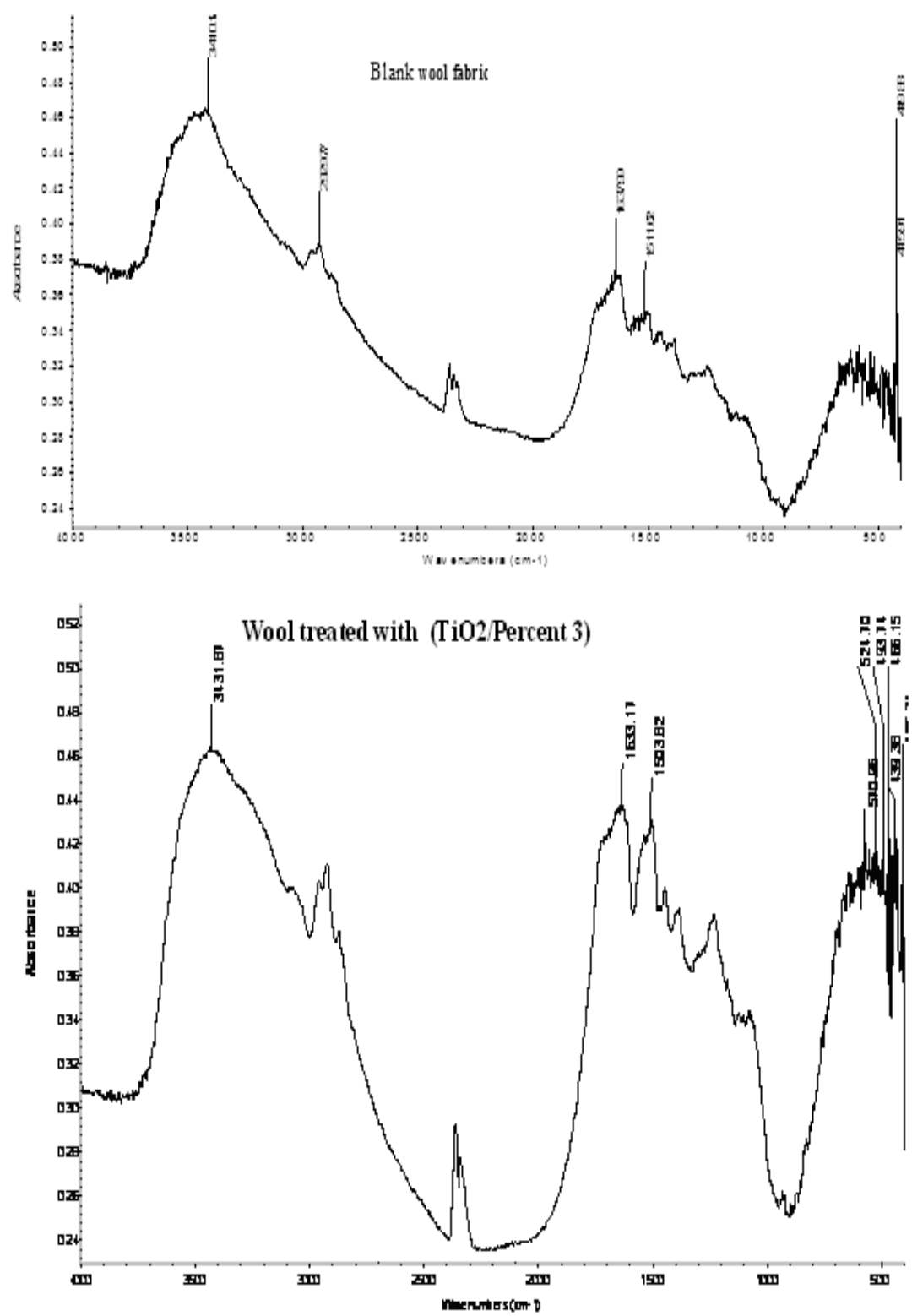

Fig.2. a-b. The IR finger print spectra of wool fabrics. 

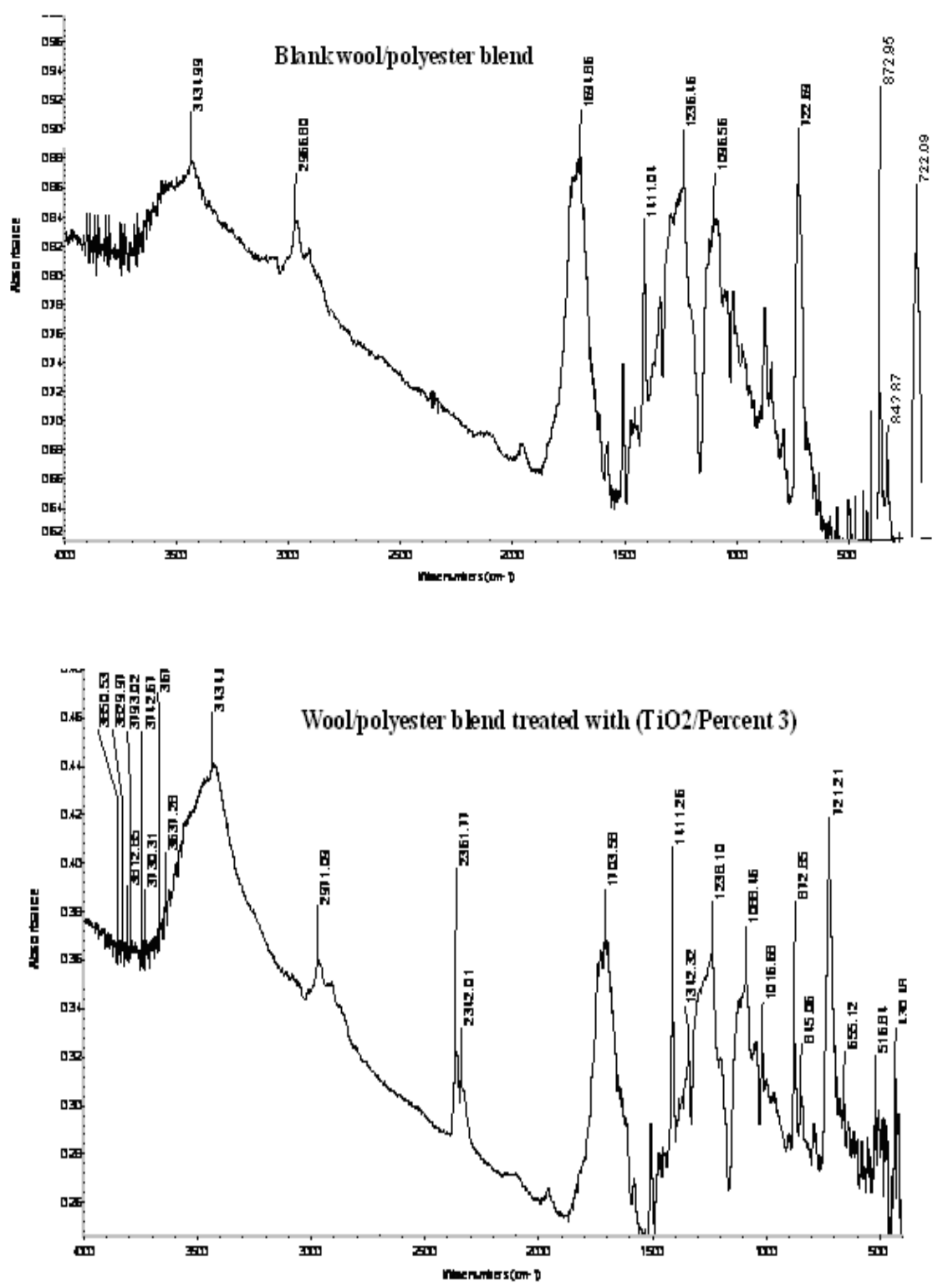

Fig. 3. a-b. The IR finger print spectra of wool/polyester-blended fabrics.

On comparing the FTIR absorbance spectra of blank untreated wool, polyester, and blend wool/polyester with those of the corresponding fabrics 
activated with nano- $\mathrm{TiO}_{2}$ as represented in (Fig. 1-3) a,b. We noticed that new characteristic peaks are appeared and located at around $558 \mathrm{~cm}^{-1}$ and $888 \mathrm{~cm}^{-1}$, as well as $794 \mathrm{~cm}^{-1}$, respectively. These peaks are corresponding to Ti-O bond in the structure of those treated fabrics. The presence of this band can support the ionic character of the new band formed due the addition of nano-titanium dioxide to the treated fabrics. The presence of absorption bands at $(3333) \mathrm{cm}^{-1}$ for $-\mathrm{OH}$ stretching and (1109) $\mathrm{cm}^{-1}$ for $\mathrm{C}-\mathrm{O}$ stretching of primary alcohols confirm the presence of PEG (overlap with $-\mathrm{OH}$ ) and $\mathrm{C}-\mathrm{O}$ functional groups of wool and wool/polyester blend fabric ${ }^{(26)}$.

Figure 4 (a-c) represented the results of collected IR absorbance intensity values of all of the characteristic functional groups of each of the treated fabrics, from which we would conclude that; for polyester fabrics the highest intensities for its characteristic functional groups were obtained at lower $\mathrm{TiO}_{2}$ concentration (i.e., $0.5 \mathrm{mg} / \mathrm{ml}$ ) while for wool the highest intensities were at higher $\mathrm{TiO}_{2}$ concentration (i.e., $3.0 \mathrm{mg} / \mathrm{ml}$ ). Finally for blend fabrics the same trend as in wool fabrics which represented the higher composition ratio in the blend this follows the rule - of- mixture behaviour, that is the resultant properties of the structure are the mean values of the volume fraction weighted properties of its constituents ${ }^{(27)}$. The increase in IR intensities of the different functional groups characterize each modified fabric could indicate the more hydrophilic nature of the surfaces of the fabric that were treated with $\mathrm{TiO}_{2}$ nanoparticles ${ }^{(28)}$.

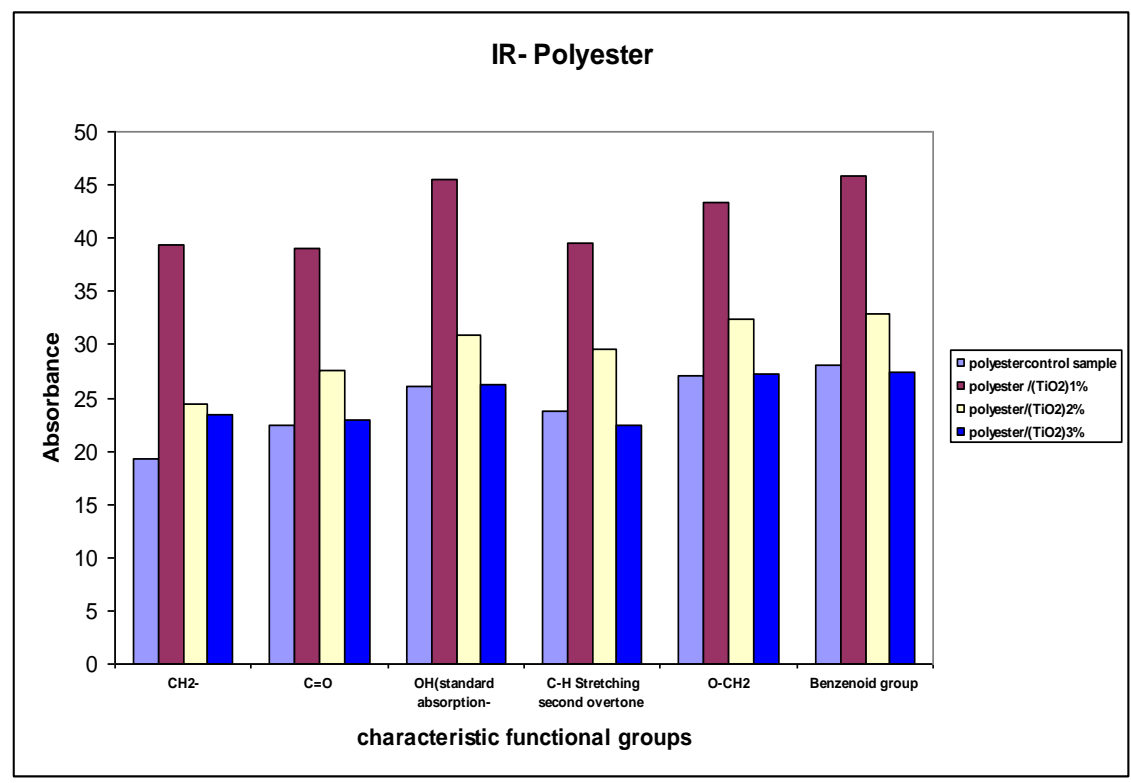

Fig. 4.a.Varition in the absorbance valus of the characteristic functional groups of different examined polyester fabrics.

Egypt. J. Chem. 59, No. 6 (2016) 


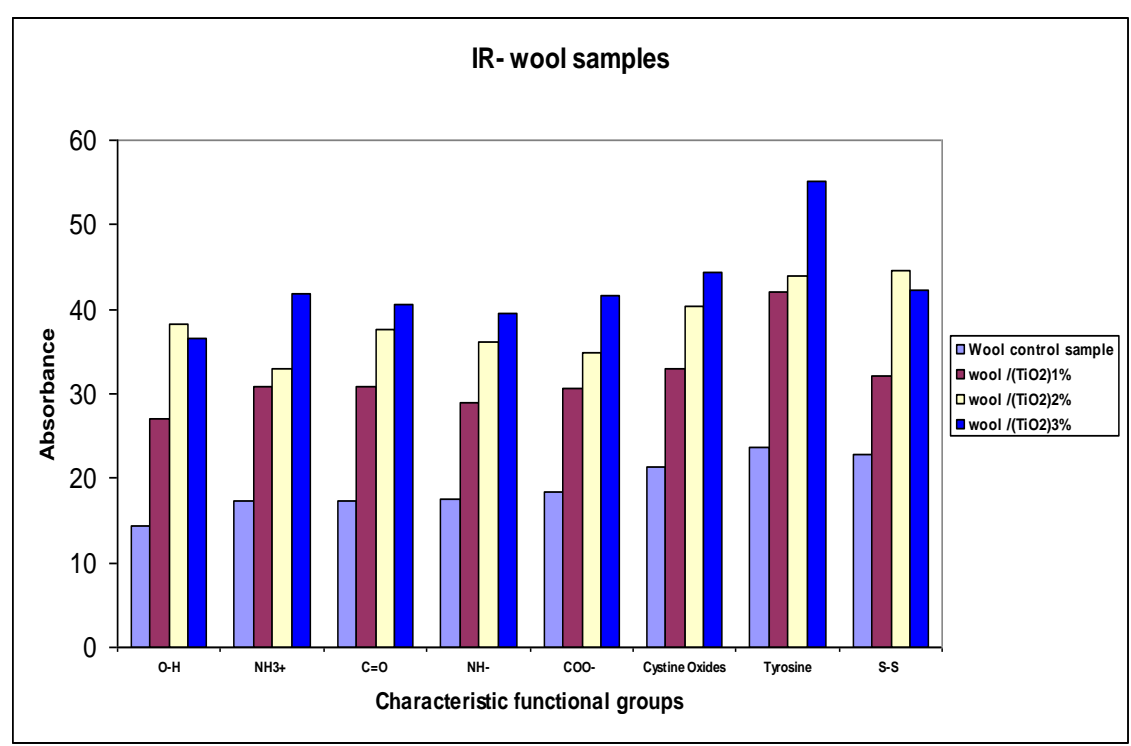

Fig. 4.b.Varition in the absorbance valus of the characteristic functional groups of different examined wool fabrics.

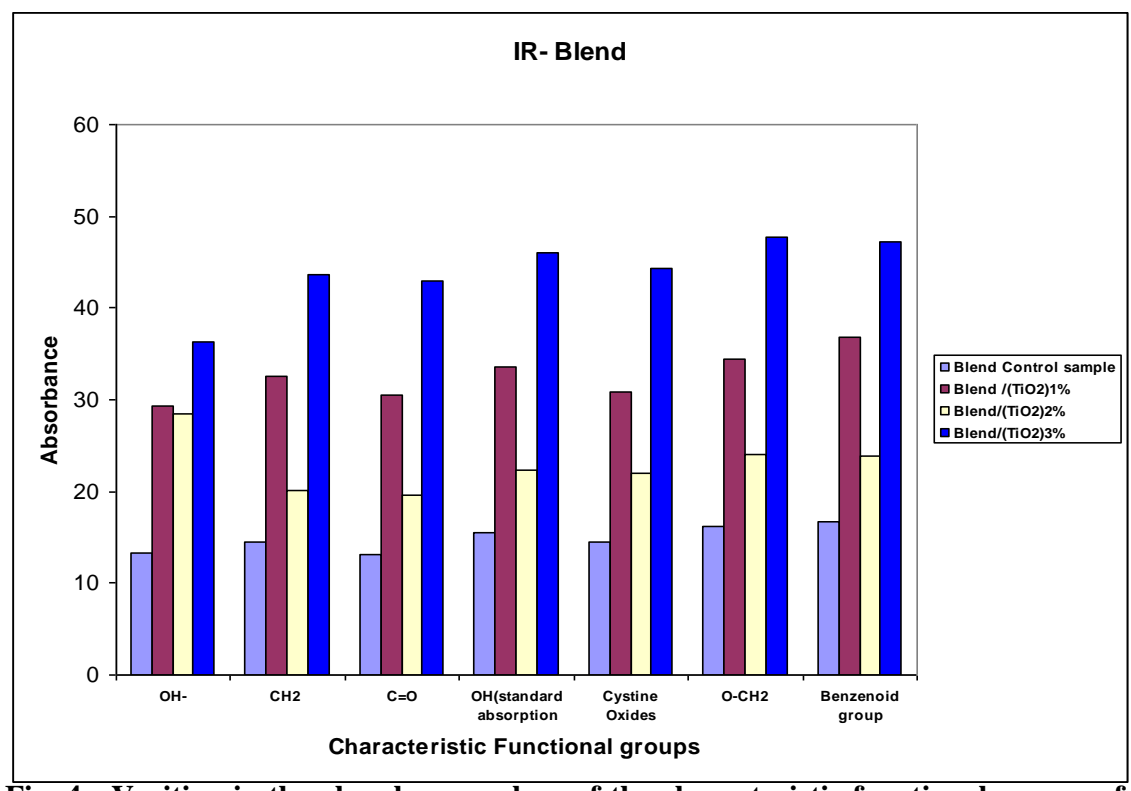

Fig. 4.c.Varition in the absorbance values of the characteristic functional groups of different examined wool/polyester blend fabrics. 


\section{Electron spin resonance (ESR) results}

Figure $5(a, b, c 1-4)$ shows the changes in electron spin resonance spectroscopy (ESR) intensity values of different fabric samples that are: wool, polyester and wool/polyester blends modified with different nano- $\mathrm{TiO}_{2}$ concentration and their blank fabrics. By analyzing of the variations in these figures we can conclude that nano- $\mathrm{TiO}_{2}$ treatment of all of the examined samples resulted in more surface activation of them within the studied concentration range. In addition the figures confirm the existence of a secondary activation peak that can be observed on following up of the different appeared peaks with intensities increased by increasing the nano- $\mathrm{TiO}_{2}$ concentration ${ }^{(18)}$. These results were agreed well with the last obtained FTIR results, which confirmed the enhanced role of titanium dioxide in the surface reactivity of the modified fabrics.

\section{Ultraviolet protection factor (UPF) results}

The UPF (ultraviolet protection factor) is a numerical rating given to clothing to indicate how effectively the fabric blocks ultraviolet (UV) radiation. Tables 1-3 showed the UPF and UV-A Transmittance (mean transmittance percentage in the visible range (290-315 nm) ,UV-B Transmittance (mean transmittance percentage in the range (315-400 nm) of different fabric samples that are: wool, polyester and wool/polyester blends treated with different nano$\mathrm{TiO}_{2}$ concentration and their blank fabrics.Generally, there is a high correlation exists between the UPF values and the fabric porosity that is influenced by the type of fibres ${ }^{(29,30)}$. The relative order of importance for the UV protection is given by $\%$ cover > fibre type > fabric thickness. Where the higher the UPF values the higher the protection. In addition, natural fibres like wool have lower degree ultra violet absorption than synthetic fibres such as polyester fabrics ${ }^{(31)}$.

On comparing the UPF values of treated fabrics with those compared with the untreated sample fabrics, it was clear that, the UPF values and the antiultraviolet performance of all of the examined nano- $\mathrm{TiO}_{2}$ treated fabrics increased by increasing the $\mathrm{TiO}_{2}$ concentration. Where, the tested samples were classified according to their UPF values ${ }^{(19)}:<15$ Poor, 15 to 24 Good, 25-39 Very Good, > 39 Excellent. Thus, the UPF value of polyester fabrics treated elevates from 13.17(poor protection) to 39.4 (Very Good protection), for wool varying from 7.5 (poor protection) to more than 50 (excellent protection), finally for blend varying from 13.91 (poor protection), to more than 50 (excellent protection).

All of these results illustrated that the anti-ultraviolet performance of all of the examined fabrics enhanced to excellent extent after being firstly treated by nano- $\mathrm{TiO}_{2}$, this is due to the powerful UV absorption and scattering capability of these fabrics pre-treated by nano- $\mathrm{TiO}_{2}{ }^{(32,33)}$ resulting in excellent UVshielding performance 

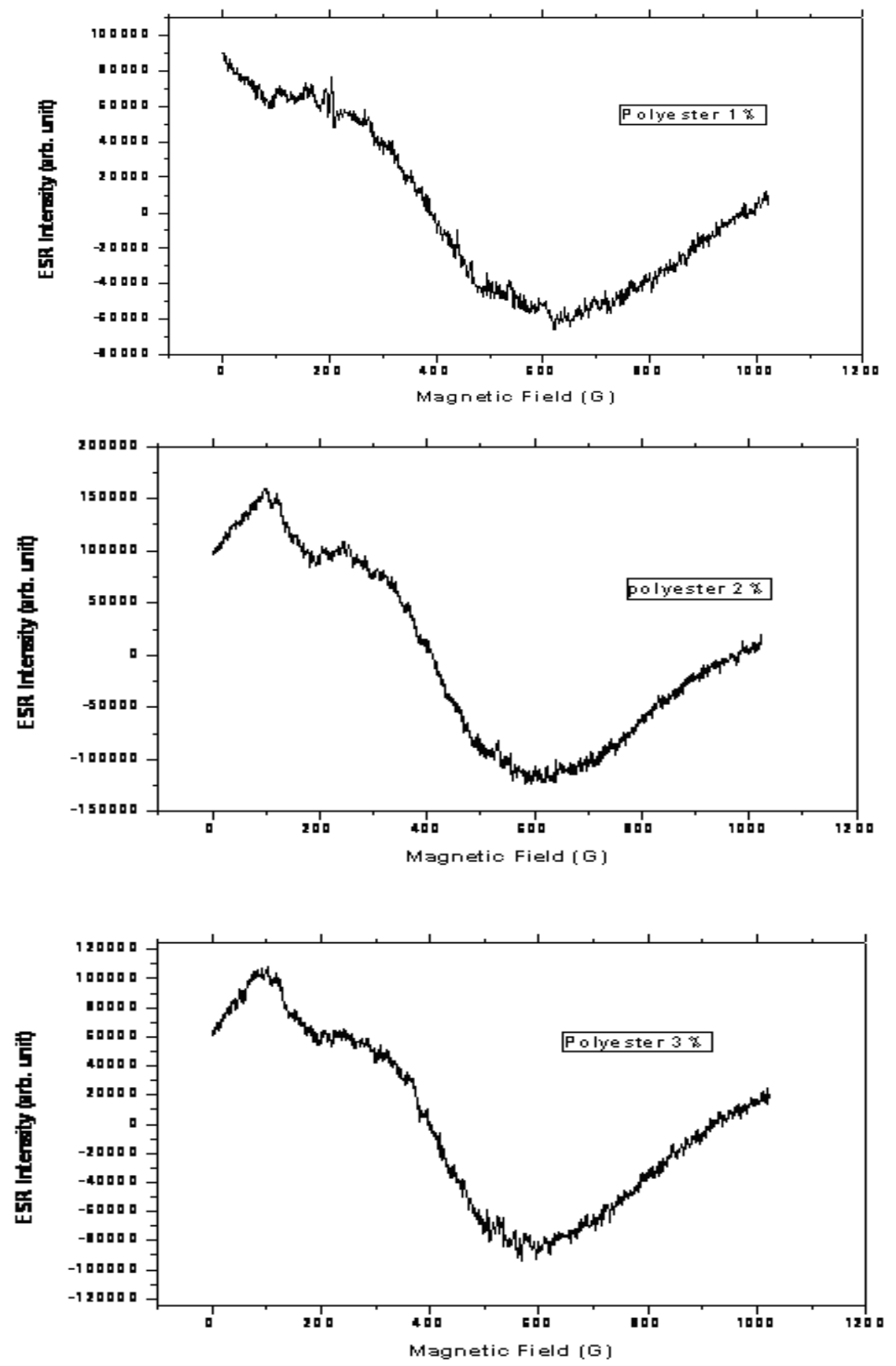

Fig. 5 (a) 1-4. The change in ESR intensity of different nano- $\mathrm{TiO}_{2} /$ treated polyester fabrics.

Egypt. J. Chem. 59, No. 6 (2016) 

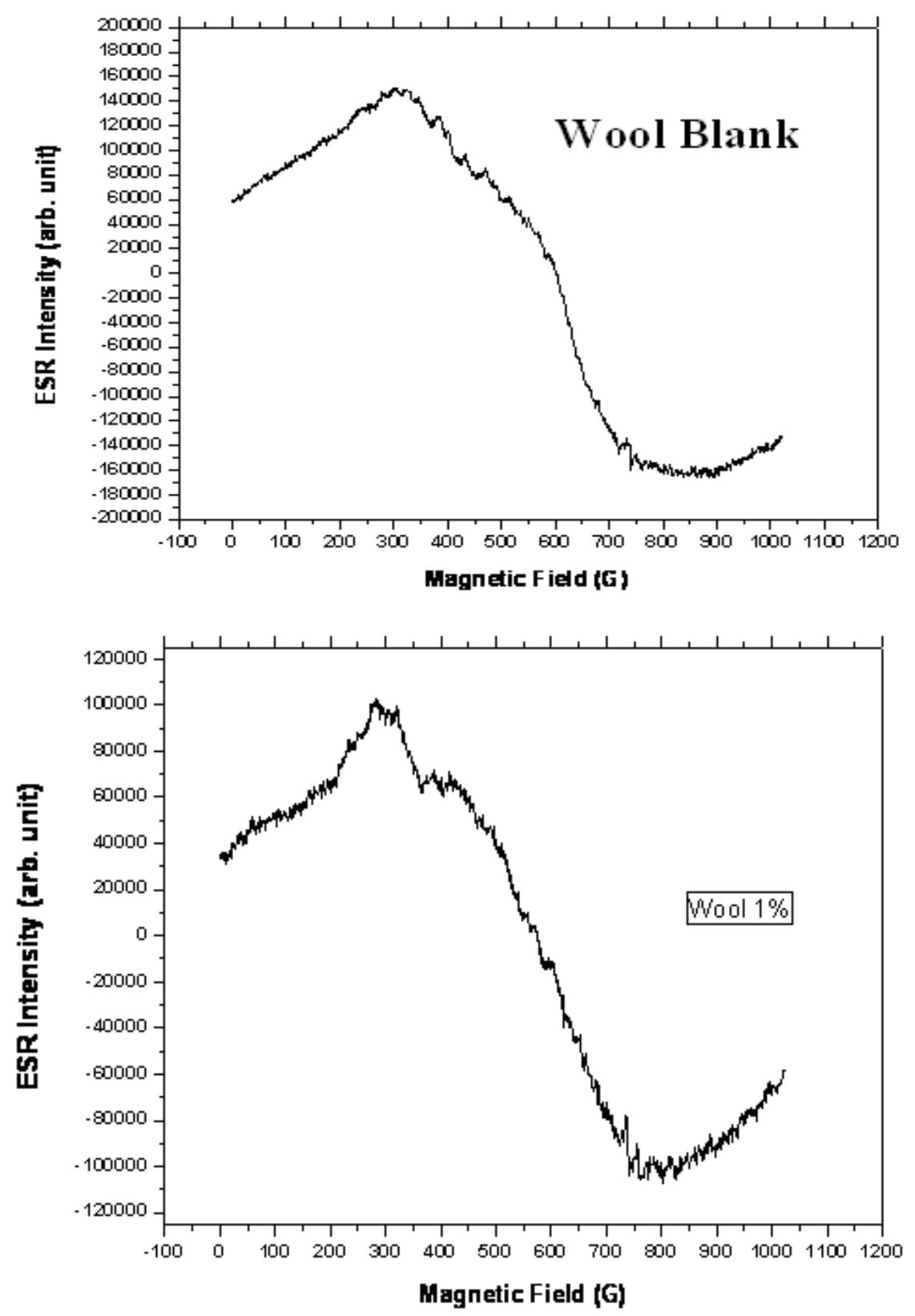

Egypt. J. Chem. 59, No. 6 (2016) 

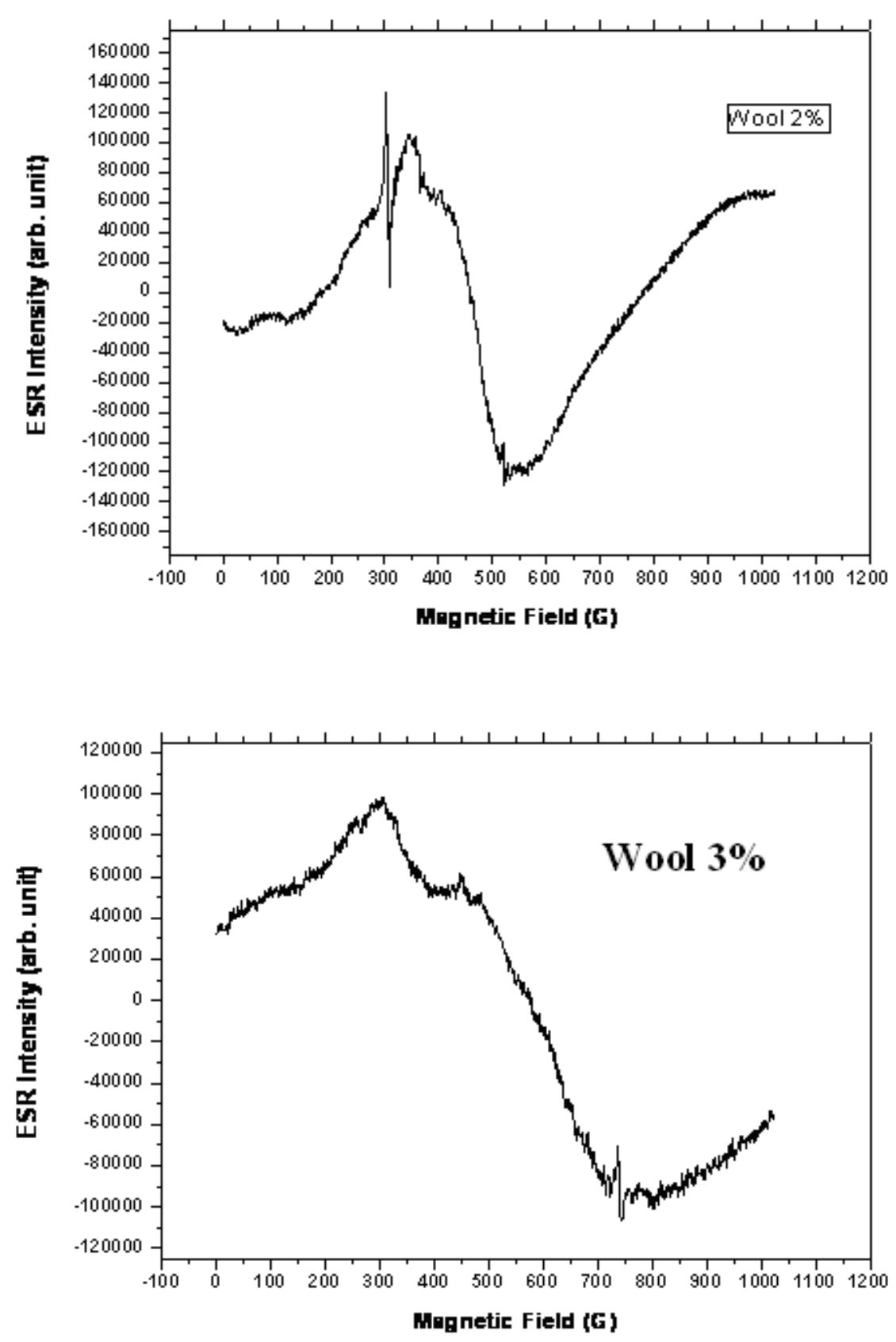

Fig. 5. (b) 1-4.The change in ESR intensity of different nano- $\mathrm{TiO}_{2} /$ treated wool fabrics. 

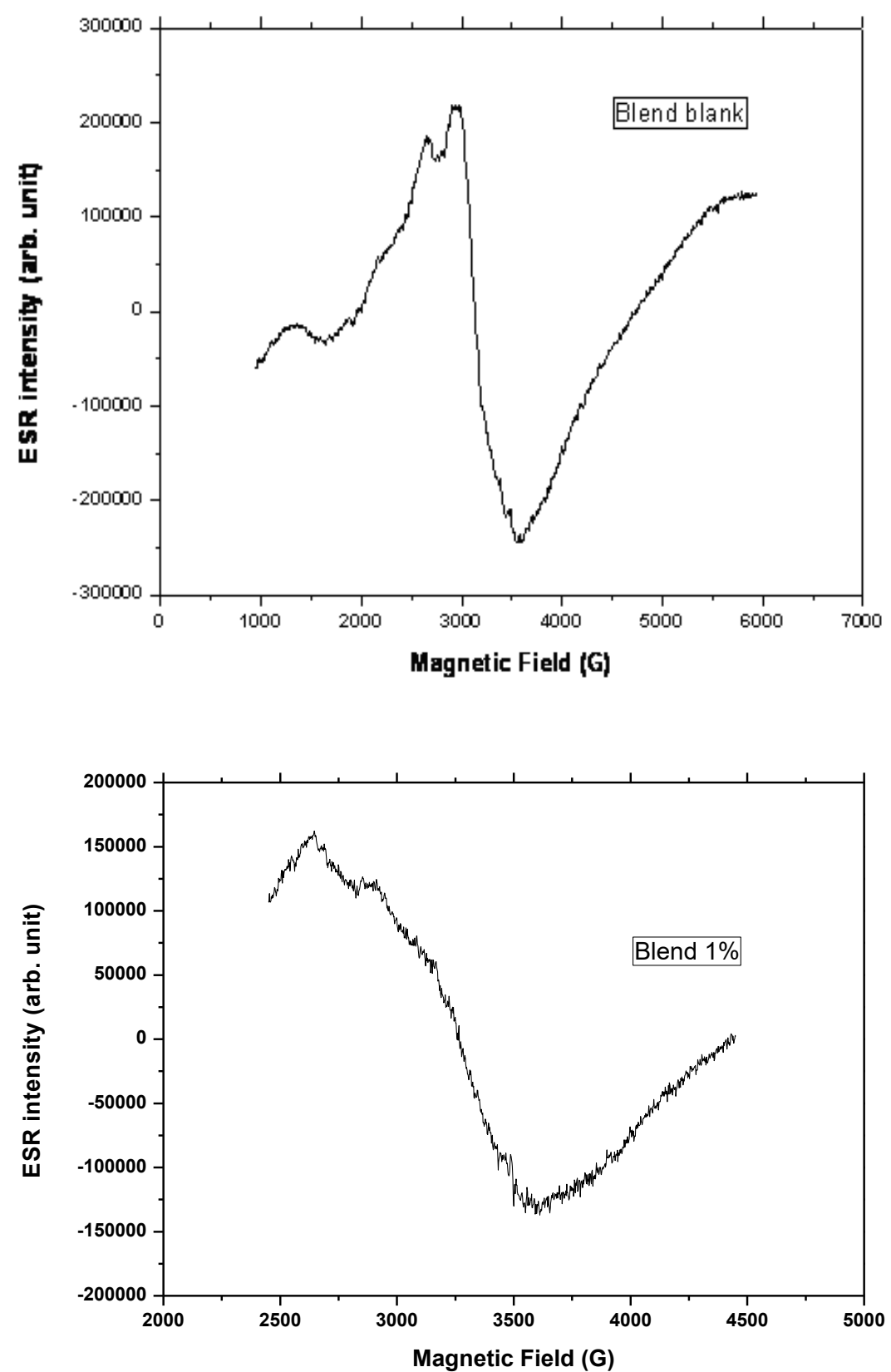

Egypt. J. Chem. 59, No. 6 (2016) 

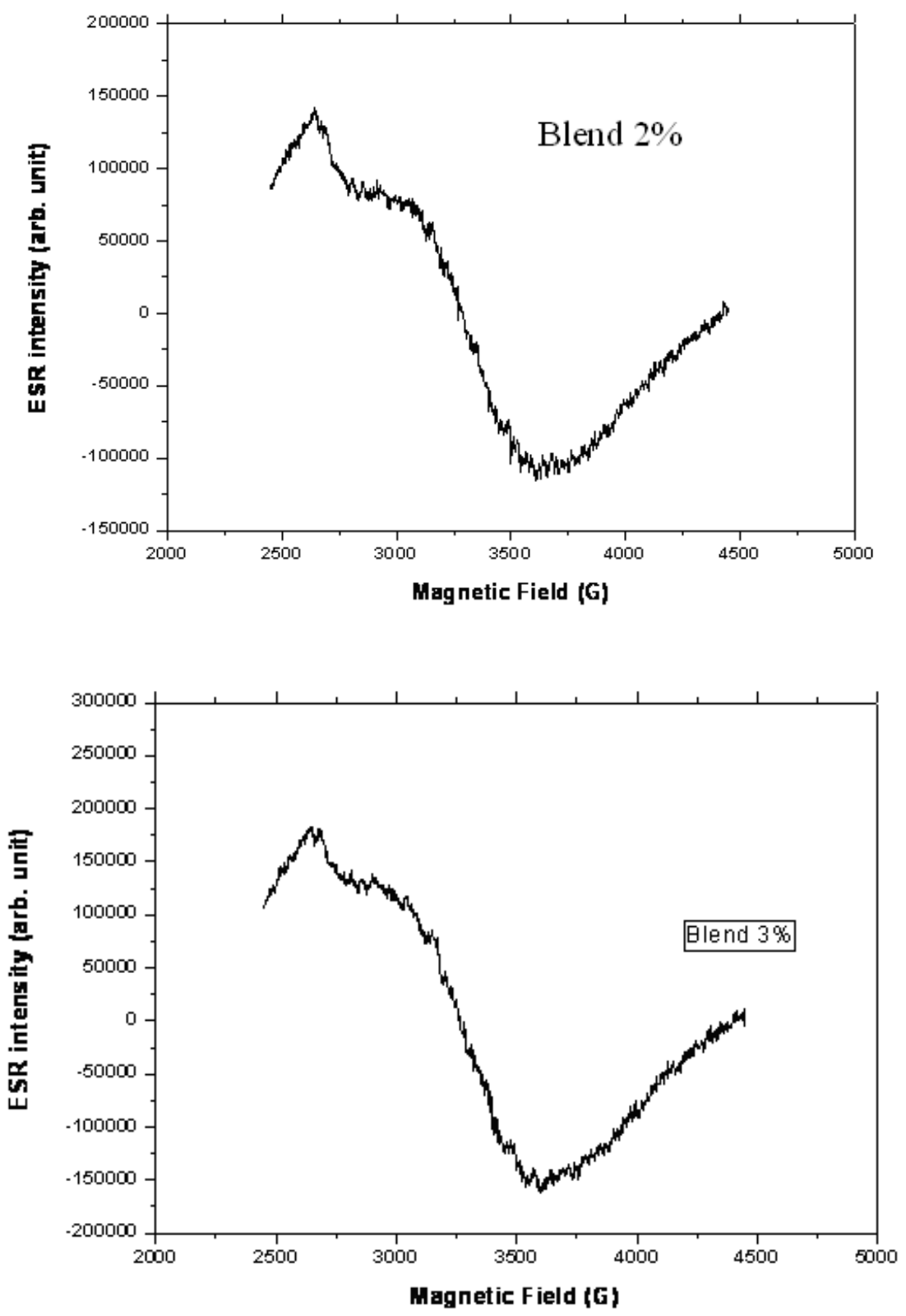

Fig. 5. (c) 1-4. The change in ESR intensity of different nano-TiO2/ treated blend fabrics. 
TABLE 1. Anti-ultraviolet performance of the different polyester fabrics.

\begin{tabular}{|c|c|c|c|}
\hline Sample & $\begin{array}{l}\text { UVA transmission } \\
\text { blockage } \% \\
(290-315 \mathrm{~nm})\end{array}$ & $\begin{array}{c}\text { UV B } \\
\text { transmission } \\
\text { blockage } \% \\
(315-400 \mathrm{~nm})\end{array}$ & UPF \\
\hline Samples (1) & 13.17 & 29.48 & $\begin{array}{cl} & 6.53 \\
\text { (poor } & \text { Protection) }\end{array}$ \\
\hline Samples (2) & 3.09 & 14.97 & $\begin{array}{c}25.8 \\
\text { (Good Protection) }\end{array}$ \\
\hline Samples (3) & 16.30 & 3.06 & $\begin{array}{c}32.1 \\
\text { (very Good } \\
\text { Protection) }\end{array}$ \\
\hline Samples (4) & 14.99 & 3.16 & $\begin{array}{c}39.4 \\
\text { (Excellent protection ) }\end{array}$ \\
\hline
\end{tabular}

Where: samples (1) refer to blank untreated fabric(Control), samples (2) refer to treated fabric with (TiO2/Percent 1), samples (3) refer to treated fabric with (TiO2/Percent 2), and samples (4) refer to treated fabric with (TiO2/Percent 3).UV-A Transmittance (mean transmittance percentage in the range (290-315 nm) and UV-B Transmittance (mean transmittance percentage in the range (315-400 nm).

TABLE 2. Anti-ultraviolet performance of the different wool fabrics.

\begin{tabular}{|c|c|c|c|}
\hline Sample & $\begin{array}{c}\text { UVA } \\
\text { transmission } \\
\text { blockage \% }\end{array}$ & $\begin{array}{c}\text { UV B } \\
\text { transmission } \\
\text { blockage \% }\end{array}$ & UPF \\
\hline Samples (1) & 13.42 & 20.94 & $\begin{array}{c}7.5 \\
\text { (poor Protection ) }\end{array}$ \\
\hline Samples (2) & 0.81 & 0.09 & $\begin{array}{c}46.1 \\
\text { (Excellent Protection ) }\end{array}$ \\
\hline Samples (3) & 0.37 & 0.07 & $\begin{array}{c}>50 \\
\text { (Excellent Protection ) }\end{array}$ \\
\hline Samples (4) & 0.5 & 0.09 & $\begin{array}{c}>50 \\
\text { (Excellent Protection ) }\end{array}$ \\
\hline
\end{tabular}

TABLE 3. Anti-ultraviolet performance of the different wool/polyester blend fabrics.

\begin{tabular}{|c|c|c|c|}
\hline Sample & $\begin{array}{c}\text { UVA } \\
\text { transmission } \\
\text { blockage \% }\end{array}$ & $\begin{array}{c}\text { UV B } \\
\text { transmission } \\
\text { blockage \% }\end{array}$ & UPF \\
\hline Samples (1) & 5.44 & 18.49 & $\begin{array}{c}13.91 \\
\text { (poor Protection ) }\end{array}$ \\
\hline Samples (2) & 9.80 & 2.69 & $\begin{array}{c}28.95 \\
\text { (very good Protection ) }\end{array}$ \\
\hline Samples (3) & 8.91 & 2.26 & $\begin{array}{c}\text { 32.81 } \\
\text { (very good Protection ) }\end{array}$ \\
\hline Samples (4) & 5.09 & 1.78 & $\begin{array}{c}>50 \\
\text { (Excellent Protection ) }\end{array}$ \\
\hline
\end{tabular}

Where: samples (1) refer to blank untreated fabric(Control), samples (2) refer to treated fabric with (TiO2/Percent 1), samples (3) refer to treated fabric with (TiO2/Percent 2), and samples (4) refer to treated fabric with (TiO2/Percent 3).UV-A Transmittance (mean transmittance percentage in the range (290-315 nm) and UV-B Transmittance (mean transmittance percentage in the range (315-400 nm).

Egypt. J. Chem. 59, No. 6 (2016) 


\section{Results of antibacterial activity}

The antibacterial activity of all examined fabric samples was evaluated towards Staphylococcus aureus (Gram-positive) and Escherichia coli (Gramnegative) after the specified contact time (24 hr). Figure 6(I) showed the photos of inhibition zone surrounding the sample of both (a) blank untreated and (b) nano$\mathrm{TiO}_{2}$-treated fabrics of the lowest concentration percent (1) $(0.5 \mathrm{mg} / \mathrm{ml})$. As the diameter of inhibition zone surrounding the sample increases, the antibacterial activity of the fabrics increases. Table 4 and Fig. 6(II) showed the values of this zone in $(\mathrm{mm})$. The results showed that, the antibacterial activity of all examined nano- $\mathrm{TiO}_{2}$-treated fabrics was improved and that both of treated wool and polyester fabrics with nano- $\mathrm{TiO}_{2}$-percent (1) showed the highest inhibition zone while for nano- $\mathrm{TiO}_{2}$ - treated blend wool/polyester percent (3) was the highest. Besides, the reactivity of antibacterial effects of treated fabrics was improved towards Escherichia coli than that towards Staphylococcus aureus.

These results can be explained [4] in view of the fact that nano titanium dioxide is a photo-catalyst that when illuminated by light of energy higher than its band-gap, electrons in $\mathrm{TiO}_{2}$ jump from the valence band to the conduction band, forming an electron and an electric hole on the photo-catalyst surface. Both these species react, respectively, with oxygen and water, with the formation of two unstable species, namely $\left[{ }^{\circ} \mathrm{O}^{-2}\right.$ ] and $\left[{ }^{\circ} \mathrm{OH}\right]$ radicals, which are very reactive and react with dirt and microorganisms degrading them to $\mathrm{CO}_{2}$ and water. Shortly, it could be stated that nano- $\mathrm{TiO}_{2}$ has the ability to kill all the tested bacteria ${ }^{(34-37)}$.

\section{Conductance measurement results}

The resistance of tested textile fabrics has been studied because of its relation to the effects of static electricity in fibrous materials. Figure 7 showed the ohmic resistance values of different fabric samples that are: wool, polyester and wool/polyester blends modified with different nano- $\mathrm{TiO}_{2}$ concentration and their blank fabrics.Generally, there was an enhanced improvement in the conductance values of all of the nano- $\mathrm{TiO}_{2}$ treated fabrics compared with the untreated fabrics. Also, the reduction percentage in ohmic resistance of the examined fabrics takes the order: wool/polyester blend $(96.77 \%)>$ polyester $(94.99 \%)>$ wool $(64.59)$ calculated with regards to ohmic resistance values of their blank mates. Where, the physical properties of nano titanium dioxide are adequate for these results ${ }^{(38)}$ as nano titanium dioxide has: (1) intrinsic n-type semiconductor characteristics to be an efficient charge separation block or channel having the effective photon generated charge transport to the electrodes and (2) the potential difference between electrons and holes enough to activate the catalytic reactions. In addition the increase in nano- $\mathrm{TiO}_{2}$ concentration highly improved the conductance values of all of the examined fabrics where, the increase in the concentration of nano$\mathrm{TiO}_{2}$ resulted in a reduction in the electrical resistance on the surface of the treated fabrics this is believed to facilitate the inter-chain hopping of charge carriers on the surface of those treated fabrics than their blank untreated fabrics thus improving the binding strength of them ${ }^{(39,40)}$. 

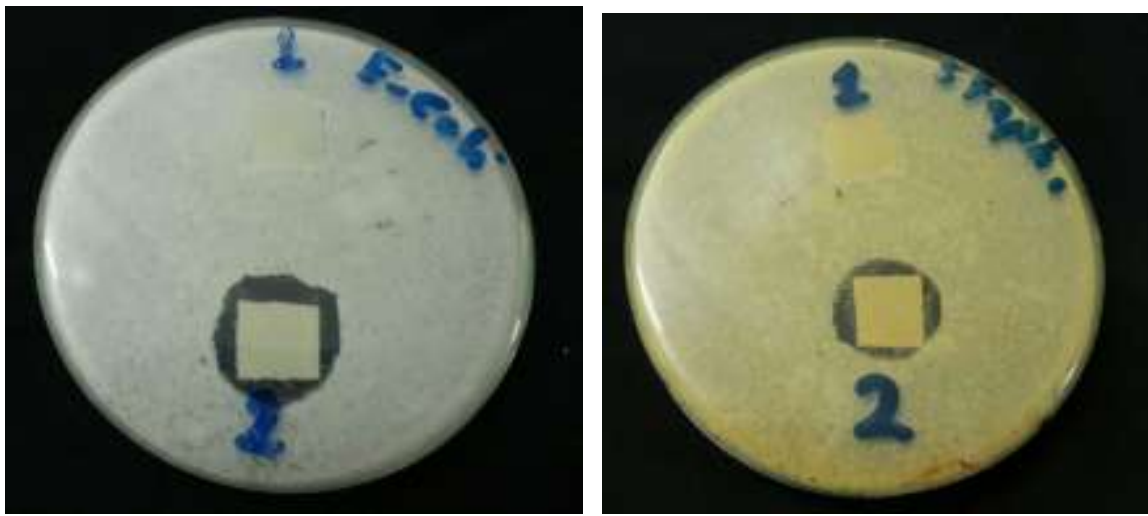

1) Blank wool, 2) Nano-TiO2 (0.5mglml) Treated wool
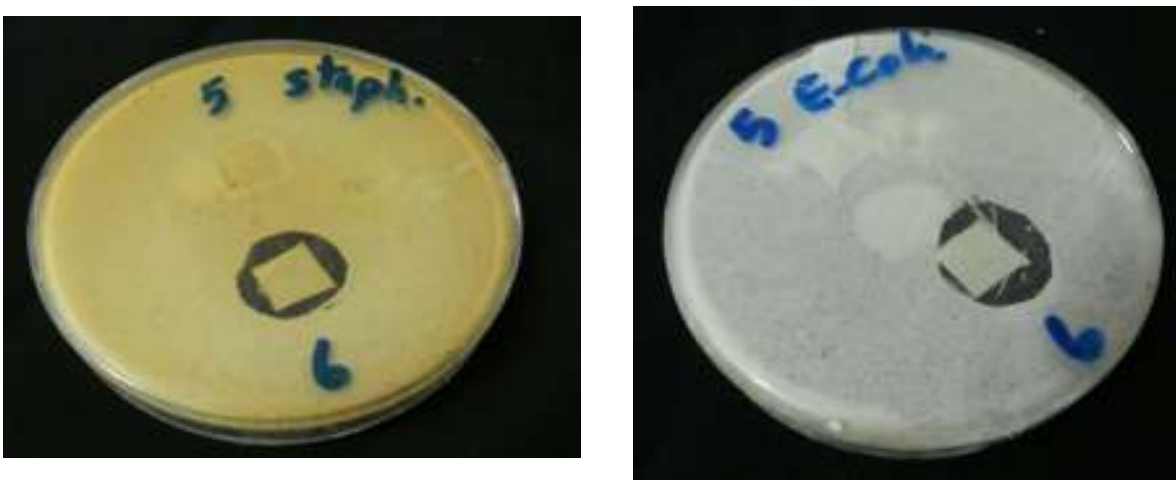

5) Blank blend , 6) Nano-TiO2 (0.5mglml) Treated blend
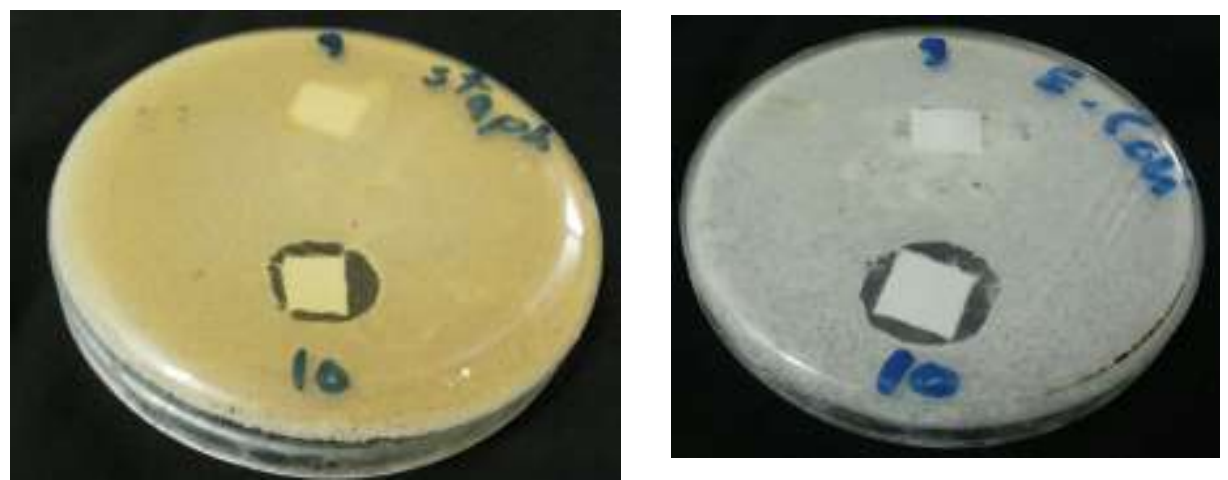

9) Blank polyester, 10$)$ Nano-TiO2 $(0.5 \mathrm{mglml})$ Treated polyester

Fig. 6. I. Photos of inhibition zone surrounding the sample of both blank untreated and nano- $\mathrm{TiO}_{2}$-treated fabrics.

Egypt. J. Chem. 59, No. 6 (2016) 


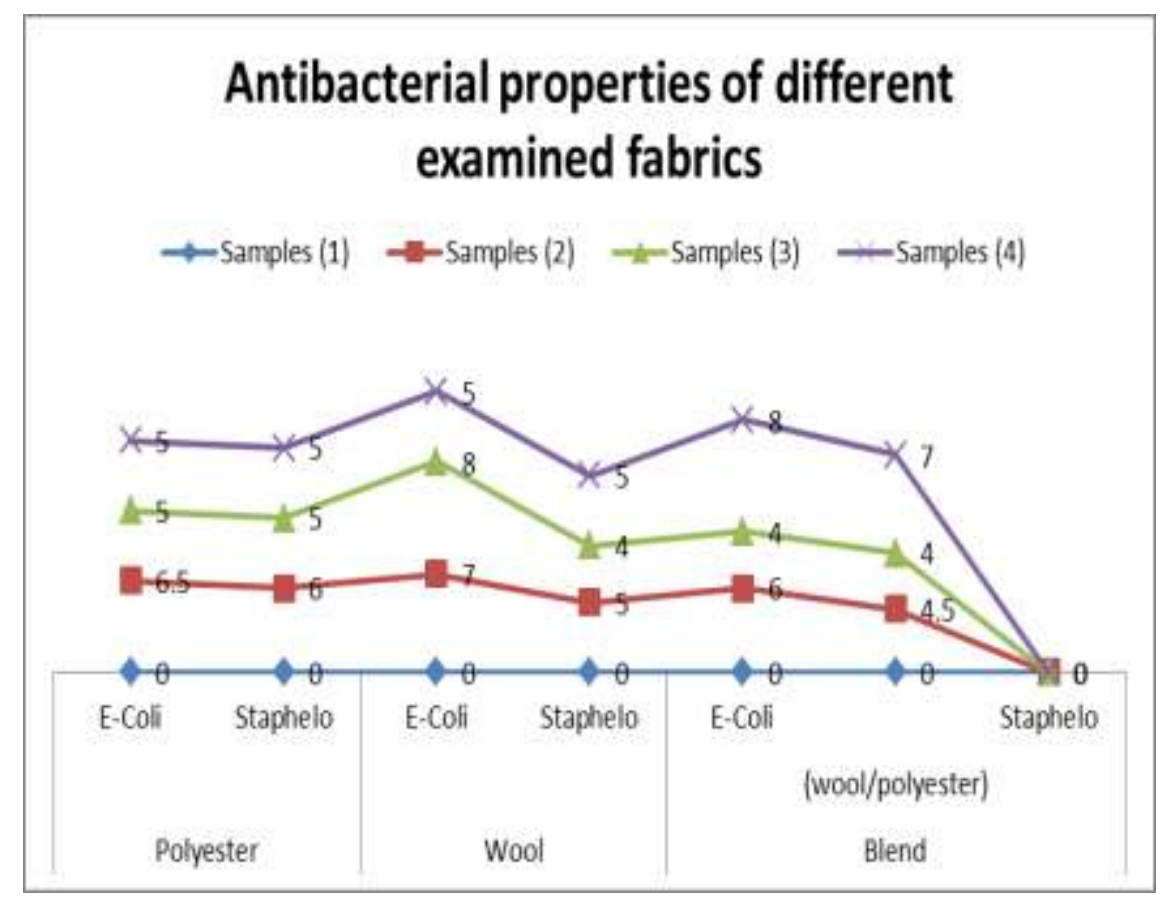

Fig.6. II.Values of inhibition zone ( $\mathrm{mm})$ of different examined fabrics .

TABLE 4. Antibacterial properties of different examined fabrics.

\begin{tabular}{|c|c|c|c|c|c|c|}
\hline \multirow{2}{*}{ Samples } & \multicolumn{6}{|c|}{ Inhibition Zone (mm) } \\
\cline { 2 - 7 } & \multicolumn{2}{|c|}{ Polyester } & \multicolumn{2}{c|}{ Wool } & \multicolumn{2}{c|}{$\begin{array}{c}\text { Blend } \\
\text { (wool/polyester) }\end{array}$} \\
\cline { 2 - 7 } & E-coli & Staphelo & E-coli & Staphelo & E-coli & staphelo \\
\hline Samples (1) & 0 & 0 & 0 & 0 & 0 & 0 \\
\hline Samples (2) & 6.5 & 6.0 & 7.0 & 5.0 & 6.0 & 4.5 \\
\hline Samples (3) & 5.0 & 5.0 & 8 & 4.0 & 4.0 & 4.0 \\
\hline Samples (4) & 5.0 & 5.0 & 5.0 & 5.0 & 8.0 & 7.0 \\
\hline
\end{tabular}

Note: zero value of inhibition zone refers to no antibacterial activity. Where: samples (1) refer to blank untreated fabric (Control), samples (2) refer to treated fabric with $\left(\mathrm{TiO}_{2} /\right.$ Percent 1$)$, samples (3) refer to treated fabric with $\left(\mathrm{TiO}_{2} / \mathrm{Percent} 2\right)$, and samples (4) refer to treated fabric with $\left(\mathrm{TiO}_{2} /\right.$ Percent 3). 


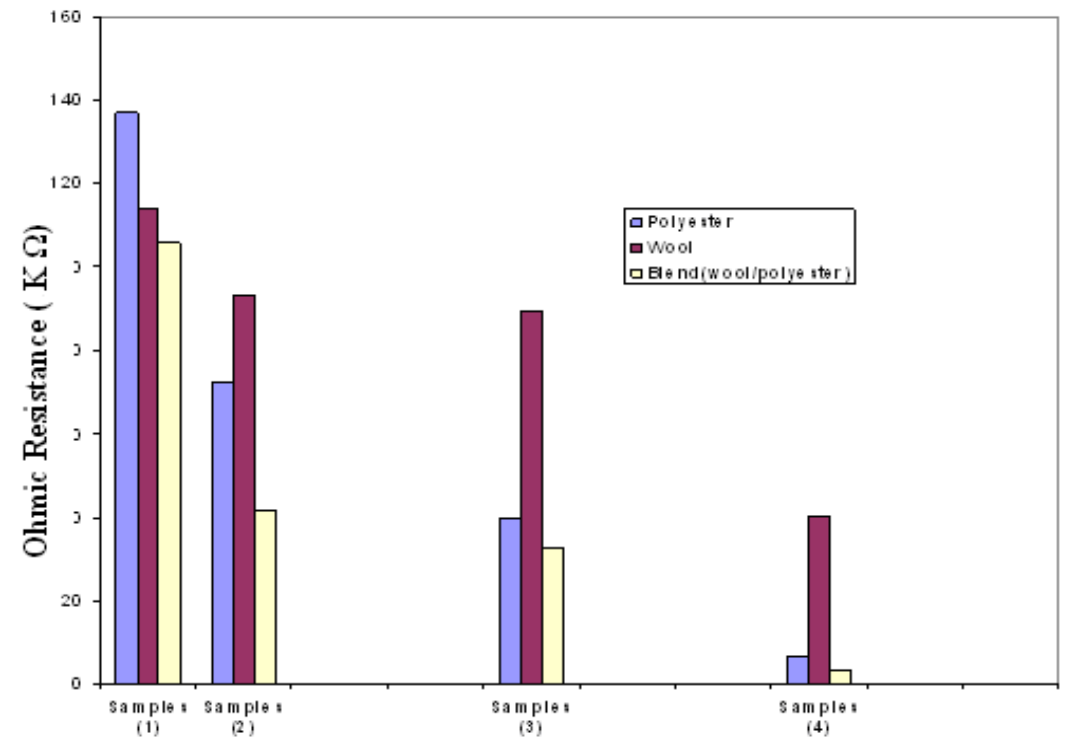

Fig. 7. Ohmic resistance results of different examined fabrics.

To blank untreated fabric(Control), samples (2) refer to treated fabric with $\left(\mathrm{TiO}_{2} /\right.$ Percent 1$)$, samples (3) refer to treated fabric with $\left(\mathrm{TiO}_{2} /\right.$ Percent 2$)$, and samples (4) refer to treated fabric with $\left(\mathrm{TiO}_{2} /\right.$ Percent 3).

\section{Air permeability results}

The results recorded in Table 5 showed the effect of treatment process of the different examined fabrics by nano- $\mathrm{TiO}_{2}$ and the effect of varying $\mathrm{TiO}_{2}$ concentration on the air permeability values of the different examined fabrics. Generally, it is clear that the air permeability values decreased for all of the modified examined fabrics than their corresponding blank samples. Such decrease may be explained by the photo-oxidation effect caused by the treatment of these fabrics by nano- $\mathrm{TiO}_{2}{ }^{(41)}$. This decrease in the air permeability values of the examined values are more pounced by increasing nano-titanium concentration resulting from the greater occupation of the nano titanium dioxide matrix in surface pores for the treated fabrics surfaces.

TABLE 5. Air permeability values of different fabrics.

\begin{tabular}{|c|c|c|c|}
\hline \multirow{2}{*}{ Samples } & \multicolumn{3}{|c|}{ Air-Permeability $\left(\mathrm{cm}^{\mathbf{3}} / \mathbf{c m} / \mathbf{S}\right)$} \\
\cline { 2 - 4 } & Polyester & Wool & $\begin{array}{c}\text { Blend } \\
\text { (wool/polyester) }\end{array}$ \\
\hline Samples (1) & 11.0 & 15.4 & 70.8 \\
\hline Samples (2) & 7.69 & 14.5 & 33.8 \\
\hline Samples (3) & 9.35 & 14.0 & 39.2 \\
\hline Samples (4) & 9.69 & 13.76 & 37.56 \\
\hline
\end{tabular}

Egypt. J. Chem. 59, No. 6 (2016) 


\section{Conclusions}

According to the results discussed and presented above, nano- $\mathrm{TiO}_{2}$ can be considered as a surface active agent for all the fabrics under study (wool, polyester and wool/polyester blend|);

1-The increase in IR intensities of the different polar functional groups characterize each fabric could indicate the more hydrophilic nature of the surfaces of the fabric that were treated with $\mathrm{TiO}_{2}$ nanoparticles.

2-The ESR results confirmed the existence of a second activation peak that can be observed on following up of the different appeared peaks by increasing the nano- $\mathrm{TIO}_{2}$ concentration

3-Treated fabrics demonstrate excellent anti-ultraviolet performance due to the powerful UV absorption and scattering capability, these treated fabrics with improved uv protection properties referred as called cosmetic-textiles.

4- The antibacterial activity of all examined nano- $\mathrm{TiO}_{2}$-treated fabrics was improved, resulted from the ability of nanoTiO ${ }_{2}$ to kill all the tested bacteria.

5-The reduction percentage in ohmic resistance of the examined fabrics takes the order: wool/polyester blend $(96.77 \%)>$ polyester $(94.99 \%)>$ wool, these were calculated with regards to ohmic resistance values of their blank mates. thus treated fabrics with improved electrical properties are refereed as smart textiles

6-The air permeability values decreased for all of the examined treated fabrics than their corresponding blank samples.

\section{References}

1. Xin J.H., Daoud, W.A., and Kong, Y.Y., A, New approach to UV-blocking treatment for cotton fabrics. Textile Research Journal, 74, 97-100, (2004).

2. Subhranshu S. S., Jeyaraman P. and Vinita, V., Sonochemical coating of Ag$\mathrm{TiO} 2$ nanoparticles on textile fabrics for stain repellency and self-cleaning- A review. Journal of Minerals \& Materials Characterization \& Engineering, 9(6), 519-525, (2010).

3. Yeo, S.Y., Lee, H.J. and Jeong, S.H., Preparation of nanocomposite fibers for permanent antibacterial effect. Journal of Materials Science, 38, p. 2143-2147, (2003).

4. Haixia, Li, Hua, D. and Jing, Z., Performance research of polyester fabric treated by nano titanium dioxide nano- $\mathrm{TiO}_{2}$ anti-ultraviolet finishing. International Journal of Chemistry, 1 (1), 57-62 (2009) .

5. Hadziioannou G., Hutten, P.F.V., Wiley-V.C. and Weinheim, H., Semiconducting Polymers, 2, (2007).

6. Morrison, S. R., Electrochemistry at Semiconductor and Oxidized Metal Electrodes; Plenum Press: New York (1980). 
7. Wong, Y. W. H., Yuen, C. W. M., Leung, M. Y. S., Ku, S. K. A. and Lam, H. L., Selected Application of Nanotechnology in Textiles, AUTEX Research Journal, 6 (1), (2006).

8. Muneer. M. B., Abdul, A. H. K., Abu Bakar, M. and Mohd, S.T., Synthesis and catalytic activity of $\mathrm{TiO}_{2}$ nanoparticles for photochemical oxidation of concentrated chlorophenols under direct solar radiation. International Journal of Electrochem. Science, 7, 4871-4888 (2012).

9. Shalaby, S.E., Abo El-Ola, S.M., AL-Blakocy, N.G., Beliakova, M.K. and Afify, H., Effect of surface activation method of pet and pet/c blended fabrics on its functional finishing with $\mathrm{TiO}_{2}$ nanoparticles. Journal of Applied Sciences Research, 9(3), 1731-1742 (2013).

10. Dong, W.G. and Huang, G., Research on properties of nano polypropylene/ $/ \mathrm{TiO}_{2}$ composite fiber. Journal of Textile Research, 23, 22-23 (2002).

11. Elvio, M., Piergiorgio, Z., Jose C. and Rosa S., Observatory Nano, Report on Nanotechnology \& Textiles Medical, Sport/Outdoor Textiles April (2010).

12. Siwińska-Stefańska, K., Ciesielczyk, F., Jesionowski, T., Sójka-Ledakowicz, J., Lota W. and Walawska A., Evaluation of the photocatalytic properties of textile fabrics modified with titanium dioxide of anatase structure. Fibres \& Textiles in Eastern Europe, 19(2), 2 (85), 76-83, (2011).

13. Matej, S., Metka F., Jana, P., and Sasa, N., Titanium dioxide in our everyday life; is it safe? Radiology and Oncology, 45 (4), 227-247 (2011).

14. Tang, H., Prasad, K., Sanjinbs, R., Schmid, P.E. and Levy, F., Electrical and optical properties of $\mathrm{TiO}_{2}$ anatase thin films. Journal of Applied Phys. 75, 2042 2047 (2004).

15. Augustynski, J., The role of the surface intermediates in the photoelectrochemical behaviour of anatase and rutile $\mathrm{TiO}_{2}$. Electrochimica Acta. 38, 43 (1993).

16. Hewitt, J.P., Titanium dioxide: a different kind of sunshield, Drug Cosmet Ind., 151, 26-32 (1992).

17. Fujishima, A., Zhang, X., Tryk, D.A., $\mathrm{TiO}_{2}$ photocatalysis and related surface phenomena. Surf. Sci. Rep. 63, 515-582 (2008).

18. Shao, J., Carr, C.M., Rowlands, C.P. and Walton, J., XPS, SIMS, and ESR studies of uv/ozone -irradiated silk and wool. Journal of Textile Institute, 90, part 1, (4), 459-468 (1999).

19. AS/NZS 4399, Sun protective clothing-evaluation and classification. Published jointly by Standards Australian and Standards New Zealand (1996).

20. Deng, H., Deng, B. and Xiao, C.,Nano-materials in UV protection textiles. Textile Asia. 6, 40-42 (2007).

Egypt. J. Chem. 59, No. 6 (2016) 
21. AATCC Test Method 147, Antibacterial activity assessment of textile material: parallel streak Method. AATCC 147 (2004).

22. Chao, H.X., Jia, C., Yina, W., Shun-Tian, J., and Jian, Z. M., Applied Surface Science, 258, 468-472 (2012).

23. Air permeability standard test method: ASTM, G: 23(1990).

24. Bezrodna,T., Gavrilko,T., Puchjovska,G. Shimanovska, V., Baran, J. and Marchewka, M., Spectroscopic study of $\mathrm{TiO}_{2}$ (rulite)-benzophenone heterogenous systems. Journal of Molecular Structure, 614, 315-324 (2002).

25. Radim B. and Horst K., Tuning the optical and photoelectrochemical properties of surface-modified $\mathrm{TiO}_{2}$ h. Potochem. Photobiol. Sci., 7, 40-48 (2008).

26. Svitlana, K., Ewa, S., Wladyslaw, J., Volodymyr, S., Roman, L. and Jadwiga, S. Z., (Electokinetic and adsorption properties of different titanium dioxides at the solid/solution interface. Central European Journal of Chemistry, November, 12(11), 1194-1205 (2014).

27. Alavi, F. , Karimi, D. and Bagri A., An investigation on thermoelastic behaviour of functionally graded thick spherical vessels under combined thermal and mechanical loads. Journal of Achievements in Materials and Manufacturing Engineering, 31 (2), (2008).

28. Nakamoto, K., Infrared and Raman Spectra of Inorganic and Coordination Compounds, John Wiley \& Sons: New York, (1986).

29. Saravanan D., UV-protection-textile-materials .AUTEX Research Journal, 7(1), 53 62 (2007).

30. Thilo, G., Sebastian, R., Peter, A. and Klaus, H., Protection against ultraviolet radiation by commercial summer clothing: need for standardized testing and labeling. Bio. Med. Central Dermatology, 1-6 (2001).

31. Gambichler, T., Hatch, K.L., Avermaete, A., Altmeyer, P. and Hoffmann, K., Influence of wetness on the ultraviolet protection factor (UPF) of textiles: in vitro and in vivo measurements. Photodermatol Photoimmunol Photomed., Feb; 18 (1), 29-35 (2002).

32. Edlich, R.F., Cox, M.J., Becker, D.G., Horowitz, J.H., Nichter L.S., Britt L.D., Edlich T.J. and Long W.B., Revolutionary advances in sun protective clothing An essential step in eliminating skin cancer in our world. J. of Long Term Effects of Medical Implants, 14 (2), 105 (2004).

33. Shiva, H., Majid, M. and Abosaied R., Nano $\mathrm{TiO}_{2}$ on alkali modified polyester fabric with improved antibacterial properties, Proceedings of the 4th International Conference on Nanostructures (ICNS4) 12-14 March, Kish Island, I.R. Iran , 977979 (2012).

34. Siniša, L. M. and Ana, M.V., Methods for testing the antimicrobial activity of $\mathrm{TiO} 2$ photocatalyst. Acta Periodica Technologica, 45, 1-283 (2014).

Egypt. J. Chem. 59, No. 6 (2016) 
35. Wu, P., Xie, R., Imlay, K. and Shang, J.K., Visible-light induced bactericidal Activity of titanium dioxide co-doped with nitrogen and silver. Environ. Sci. Technol. 44, 6992-6997 (2010).

36. Radeka, M., Markov, S., Lončar, E., Rudić, O., Vučetić, S. and Ranogajec, J., Photocatalytic effects of $\mathrm{TiO} 2$ mesoporous coating immobilized on clay roofing tiles. J. Eur. Ceram. Soc. 34, 127-136 (2014).

37. Cheng, C., Sun, D.S., Chu, W.C., Tseng, Y.H., Ho, H.C., Wang, J.B., Chung, P.H., Chen, J.H., Tsai, P.J., Lin, N.T., Yu, M.S. and Chang, H.H., The effects of the bacterial interaction with visible-light responsive titania photocatalyst on the bactericidal performance. J. Biomed. Sci. 16 doi: 10.1186/1423-0127-16-7 (2009).

38. Hyungtak, S., Visible Photocurrent in chemically doped TiO2-based schottky diodes. Journal of American Ceramic Society, 98 (8) , 2470-2475 (2015).

39. Neelakandan, R., Giridev, V.R., Murugesan, M. and Madhusoothanan, M., Surface resistivity and shear characteristics of polyaniline coated polyester fabric. Journal of Industrial Textiles, 39 (2), 175-186 (2009).

40. Hersh, S.P. and Montgomery, D.J., Electrical resistance measurements on fibers and fiber assemblies. Textile Research Journal, 22 (12), 805-818 (1952).

41. Sule, S. U., Merih, S., and Hakan Akta, A., Nano-TiO2 based multilayer film deposition on cotton fabrics for UV-Protection. Fibers and Polymers, 12(2), 190-196 (2011).

(Received 15/12/2016; accepted 27/12/2016) 


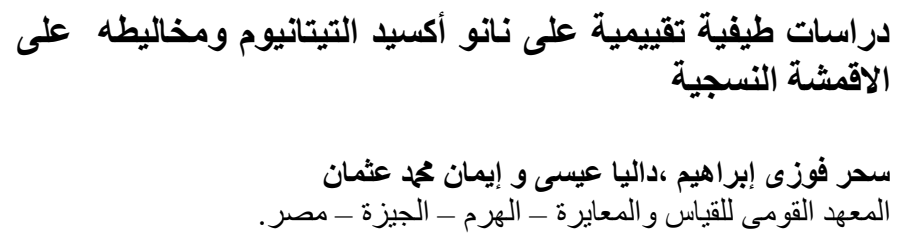

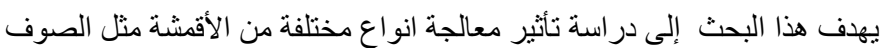
و البوليستر، ومخلوطهم (الصوف / البولئليستر) 65/35 بثاني أكسيد التيتانيوم

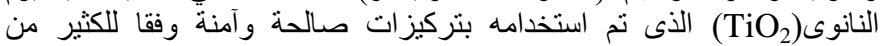

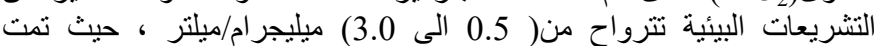

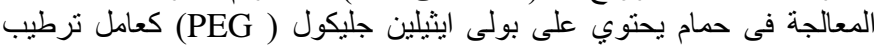

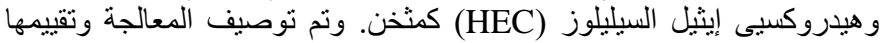

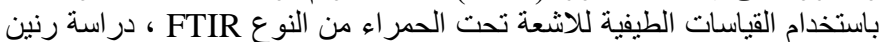

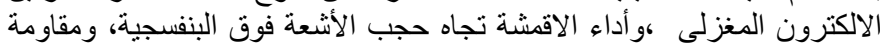

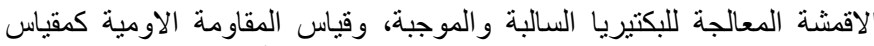

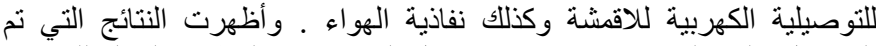

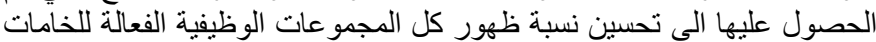
المعالجة بثاني أكسيد التيتانيوم النانوى (TiO

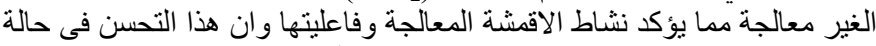

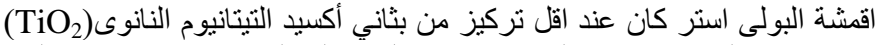

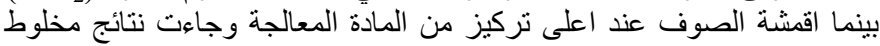

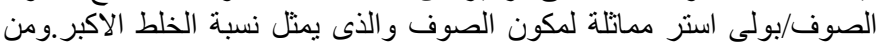

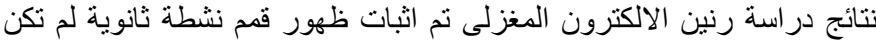

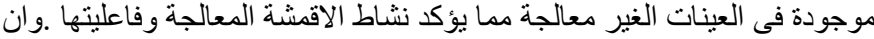

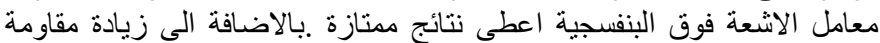

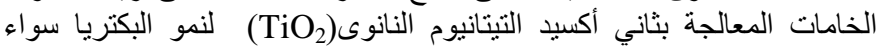

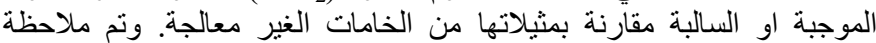

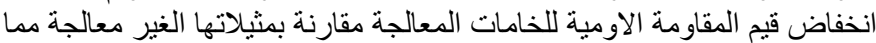
يؤكد زيادة التوصيلية الكهربية. 